\title{
EMBARREIRANDO A DEMOCRACIA
}

\author{
Carlos Marden ${ }^{1}$ \\ Pedro Alexandre Menezes Barbosa ${ }^{2}$
}

\section{RESUMO}

O presente trabalho busca analisar até que ponto a figura da cláusula de barreira é compatível com o Estado Democrático de Direito Brasileiro. Para tanto, far-se-á inicialmente uma exposição da Lei $n^{\circ}$ 9.096/95 e do julgamento realizado pelo STF nas ações diretas de inconstitucionalidade que questionavam essa imposição aos partidos políticos. Na sequência, será apresentada a Emenda Constitucional $n^{\circ}$ 97/17. A metodologia utilizada foi pesquisa bibliográfica e análise de jurisprudência. $\mathrm{O}$ objetivo geral é demonstrar que há uma diferença entre o tratamento dado pelos instrumentos normativos discutidos, fazendo com que a cláusula de barreira possa subsistir em seu modelo atual.

Palavras-Chave: Democracia. Cláusula de barreira. Partidos políticos. Supremo Tribunal Federal. Controle de Constitucionalidade.

\section{BLOCKING DEMOCRACY}

\begin{abstract}
The work seeks to analyze the extent to which the figure the barrier clause is compatible with the Democratic State of Brazilian Law. To this end, Law No. 9,096 / 95 and the judgment made by the STF in the direct unconstitutionality actions that questioned this imposition on political parties will initially be presented. Then, Constitutional Amendment No. 97/17 will be presented. The methodology used was bibliographic research and analysis jurisprudence. The general objective is to demonstrate there is a difference between the treatment given by the normative instruments discussed, making the barrier clause to exist in its current model.
\end{abstract}

KeyWords: Democracy. Barrier clause. Political parties. Federal Supreme Court. Constitutionality Control.

\section{INTRODUÇÃO: DEMOCRACIA, PLURALISMO E PROLIFERAÇÃO DE PARTIDOS POLÍTICOS.}

\footnotetext{
${ }^{1}$ Procurador Federal. Graduado em Direito, Especialista em Direito Processual Civil e Mestre em Ordem Jurídica Constitucional pela Universidade Federal do Ceará - UFC. Doutor em Direito Processual pela Pontifícia Universidade Católica de Minas Gerais. Pós-doutor em Estado, Democracia e Constituição pela Universidade do Vale do Rio dos Sinos. Professor do Programa de Pós-Graduação do Centro Universitário Christus UniChristus. e-mail: carlosmardencc@hotmail.com.

${ }^{2}$ Procurador Federal. Graduado em Direito pela Universidade Federal do Ceará - UFC. Especialista em Direito do Estado pela Associação Educacional Unyahna e em Direito Processual Civil pela Escola da Assembleia do Rio Grande do Norte. Mestrando no Programa de Pós-Graduação do Centro Universitário Christus UniChristus. e-mail: pedroamb@gmail.com.
} 
No início do Século XX, a Democracia tinha ressurgido no Ocidente, mas ainda buscava um design que lhe conferisse legitimidade, sem comprometer a sua funcionalidade (TOCQUEVILLE, 2007). Há significativo consenso no sentido de que coube a Hans Kelsen (2003) o papel de apontar não apenas a inviabilidade de se praticar a Democracia Direta nas sociedades contemporâneas (tanto complexas quanto populosas), mas também o de sugerir que a Democracia só seria possível se organizada a partir da lógica dos partidos políticos. A partir de então, a tecnologia partidária passou a ser central na forma de configuração das democracias que se espalharam ao longo do Século XX. Entretanto, mesmo no início do Século XXI, ainda existe razoável margem de variação entre os modelos adotados nos diferentes países, fazendo com que persista a busca por uma sintonia fina capaz de fornecer a melhor configuração para os sistemas democráticos.

Nesse cenário, certamente um dos pontos mais delicados consiste em saber quantos partidos devem ser admitidos e fomentados. Por um lado, a existência de um número significativo de partidos se mostra como favorável à pretensão de refletir a complexidade da sociedade. Por outro lado, um excesso de partidos pode resultar numa fragmentação políticoeleitoral que dificulte a formação de consensos, sirva de obstáculo ao funcionamento do Parlamento e alimente o discurso de minorias que verão seu discurso radical ser representado em exagero. Por tal motivo, vários países do Ocidente adotaram mecanismos para tentar encontrar o modelo ótimo no qual o surgimento de partidos seja suficientemente aberto para permitir vazão à pluralidade social, mas seja parcialmente fechado para evitar um crescimento inflacionário descontrolado.

Este dilema também foi objeto de atenção no Brasil e é o objeto da presente pesquisa, especialmente no que se refere à introdução do mecanismo de cláusula de barreira. O recurso a tal figura de contenção já havia sido tentado no fim do século passado, sem que o design então adotado prosperasse junto ao Supremo Tribunal Federal. Sendo assim, um novo design foi apresentado no começo deste século, com a pretensão de ser constitucionalmente adequado. Percebe-se, portanto, que a análise da figura da cláusula de barreira mostra-se não apenas como um tema de extrema relevância (na medida em que vem sendo objeto de atenção por parte do Poder Legislativo), mas também de plena atualidade (vez que a última alteração legislativa permanece em vigor). Ao estudar as tentativas de introduzir a cláusula de barreira, este trabalho acaba por estudar a forma como o Brasil busca sintonizar a sua Democracia. 
Para tanto, será inicialmente apresentada a cláusula de barreira conforme foi introduzida no Ordenamento Jurídico brasileiro pela Lei $\mathrm{n}^{\circ}$ 9.096/95, como forma de descrever a tentativa original de limitar a proliferação de partidos políticos (apenas dez anos após a redemocratização). O objetivo de tal tópico é descrever uma opção política que veio a ser questionada judicialmente, tendo sido considerada como incompatível com os limites do texto da Constituição Federal. Na sequência, serão analisadas as ações diretas de inconstitucionalidade que tramitaram no Supremo Tribunal Federal e acabaram por expurgar a cláusula de barreira do Ordenamento Jurídico. A análise de tal julgamento é de suma importância, na medida em que se busca entender as incompatibilidades apontadas e discutir sua eventual persistência.

O tópico seguinte é dedicado a analisar o conteúdo da Emenda Constitucional $\mathrm{n}^{\circ}$ 97/17, que novamente introduziu a cláusula de barreira no Direito brasileiro (desta vez com status de nível superior diferenciado). Procura-se descrever a nova configuração do mecanismo de contenção, com foco nas diferenças e semelhanças que eventualmente guarde com o modelo anterior. Usando tais comparações como matéria-prima, parte-se para uma análise crítica à luz dos argumentos que o Supremo Tribunal Federal veiculou em suas decisões anteriores, quando apontou a inconstitucionalidade da cláusula de barreira original. O objetivo deste ponto é argumentar que as objeções apresentadas pelo Supremo Tribunal Federal (ainda que tidas como pertinentes no julgamento das ações diretas de inconstitucionalidade) não podem ser estendidas para impugnar a nova cláusula de barreira introduzida pela Emenda Constitucional n 97/17.

Com o fim da Ditadura Militar (em 1985), o Brasil vive atualmente o mais longo período de Democracia em toda a sua história, mas ainda assim deve ser considerado como uma Democracia em amadurecimento. Por tal motivo, é natural que a legislação pertinente esteja periodicamente passando por uma série de mudanças que buscam aprimorar o sistema político-eleitoral, na busca de conceder maior funcionalidade (e legitimidade) à tecnologia partidária típica das Democracias indiretas e representativas que predominam no Ocidente. No momento, a busca por encontrar o ponto ótimo de receptividade ao surgimento de novos partidos políticos é uma questão fundamental, para a qual a cláusula de barreira tem se mostrado uma solução promissora.

Sendo assim, compreender o design da cláusula de barreira e analisar a sua compatibilidade com a Constituição Federal (à luz dos critérios definidos pelo Supremo 
Tribunal Federal) é um exercício essencial para definir o modelo de Democracia (e de Estado Democrático de Direito) que o Brasil pretende adotar. Tal missão depende de estabelecer uma análise crítica e um diálogo qualificado a respeito do papel institucional dos partidos políticos, sempre à luz das ideias de pluralismo e tolerância. Este trabalho se apresenta como uma contribuição neste sentido.

\section{DA CLÁUSULA DE BARREIRA PARTIDÁRIA INSTITUÍDA NA LEI 9.096, DE 19 DE SETEMBRO DE 1995.}

O ano era 1989, mês de março. A Constituição Federal "cidadã”, que objetivava consolidar a transição do regime brasileiro para uma democracia, havia sido promulgada poucos meses antes quando o Projeto de Lei $\mathrm{n}^{\circ} 1.670$ foi apresentado pelo Deputado Federal Paulo Delgado. Dentre os diversos dispositivos do referido projeto que visavam a regular a atividade partidária, não se imaginava que o conteúdo do artigo 13 seria objeto de tantas e tão tumultuadas reviravoltas em sua vigência, desenhando e redesenhando o quadro partidário nacional.

A redação do famigerado artigo era prosaica, de pouca complexidade interpretativa:

\footnotetext{
Art. 13. Tem direito a funcionamento parlamentar, em todas as Casas Legislativas para as quais tenha elegido representante, o partido que, em cada eleição para a Câmara dos Deputados obtenha o apoio de, no mínimo, cinco por cento dos votos apurados, não computados os brancos e os nulos, distribuídos em, pelo menos, um terço dos Estados, com um mínimo de dois por cento do total de cada um deles.
}

Dada a relevância da matéria que se pretendia regular, diversos outros projetos viriam a ser apresentados nos próximos anos sobre o mesmo assunto, sendo ao menos 14 (catorze) deles apensados ao projeto original (BRASIL, 2020, online).

Mesmo em meio à efervescência do debate político que se experimentava naquele ambiente democrático bastante jovem, o dispositivo que viria a ficar conhecido nos noticiários e em nossa cultura político-jurídica como "cláusula de barreira" ou "cláusula de desempenho" não sofreu alteração em seu texto, passando a integrar o ordenamento pátrio em 19 de setembro de 1995, quando o projeto se tornaria a Lei $\mathrm{n}^{\circ}$ 9.096. As disposições finais e transitórias da norma, entretanto, abrandavam a exigência, tornando-a gradativa, de forma que a representação ali prevista como requisito ao funcionamento parlamentar apenas viria a ser 
exigida na totalidade para a legislatura cujas eleições se dariam em 2006. Em menos de um mês de sua entrada em vigor, a lei seria atacada por duas ações diretas de inconstitucionalidade (1351 e 1354), propostas pelo Partido Comunista do Brasil - PCdoB e o Partido Socialista Cristão - PSC. Tais ações, entretanto, não seriam julgadas antes do pleito nacional de 2006.

Importante aqui esclarecer que a lei não impedia diretamente a criação, fusão, incorporação e extinção de partidos políticos. As consequências da votação insuficiente seriam: a perda da participação na quase totalidade do fundo partidário, pois entrariam no rateio de apenas $1 \%$ do total; a redução de quarenta para meros dois minutos de programas semestrais em rede nacional para divulgação de suas propostas e perda do direito aos programas em rede estadual e das inserções publicitárias; a representação partidária do congresso, sendo vedados direitos regimentais à bancada, como participações em comissões, direitos da liderança respectiva, etc. Apesar de não significar, por si só, o fim da legenda, os efeitos de não se atingir a votação mínima poderiam inviabilizar ou, ao menos, dificultar sobremaneira a participação do partido no cenário político.

As eleições de 2006, portanto, se deram sob a sombra da espada de Dâmocles. Candidaturas, coligações e campanhas foram formatadas tendo como objetivo primordial a superação da cláusula de barreira. As análises de probabilidades estatísticas dominavam o noticiário político (Consultor Jurídico, 2006, online), que já antecipava o possível contorno de distribuição de forças, com partidos maiores, mas em menor número. Conversas informais referentes a fusões e incorporações de legendas que não atingissem o "número mágico" já se faziam públicas. Todo o cenário se encontrava preparado para uma mudança profunda nas relações político-partidárias a partir da legislatura que se seguiria. De fato, o resultado das eleições iria confirmar o cenário previsto. Dos 29 (vinte e nove) partidos políticos até então regularmente constituídos, apenas 07 (sete) atingiriam, inicialmente, o percentual exigido na legislação, ainda que 20 (vinte) viessem a obter assento no Congresso (MATAIS, 2006, online).

Antes mesmo do início da legislatura respectiva, fusões (GUERREIRO, 2006, online) e incorporações (PTB, 2006, online) chegaram a ser realizadas, ampliando levemente tal número. A formação de blocos de agremiações que, somadas, satisfariam o requisito para o pleno funcionamento parlamentar, aparecia como mais uma alternativa. Ocorre que, no curto espaço de tempo entre o resultado do pleito e o início da legislatura, o plenário do Supremo 
Tribunal Federal resolveu resgatar as ações diretas de inconstitucionalidade propostas no ano de 1995. Os partidos proponentes, coincidentemente, não haviam satisfeito a condição numérica. As mencionadas ações alegavam, em suma, que as condições restritivas trazidas pela Lei $\mathrm{n}^{\circ}$ 9.096/95 feriam o princípio da liberdade e da autonomia partidária, violando o art. 17, caput e $\S 1^{\circ}$, da Constituição Federal.

\section{O JULGAMENTO DAS AÇÕES DIRETAS DE INCONSTITUCIONALIDADE 1351 E 1354.}

As ações diretas de inconstitucionalidade 1351 e 1354 foram apensadas e julgadas conjuntamente. Para os fins a que se pretende o presente artigo, é fundamental compreender a ratio decidendi do acórdão que resultou de seu julgamento. Como ensina Juraci Mourão Lopes Filho (2020, p. 124), os sumários emitidos pelas cortes não se prestam à função de precedente. Para conhecê-lo adequadamente, há de se conhecer a decisão por inteiro, analisando todos os elementos de fato e de direito nela utilizados. Os argumentos utilizados nos debates e a fundamentação de cada voto irão nos guiar nessa busca, motivo pelo qual se passa a analisar as teses trazidas aos autos e o raciocínio por trás da decisão.

$\mathrm{Na}$ defesa da constitucionalidade do dispositivo, o Advogado-Geral da União alegou que o artigo 13 da Lei $n^{\circ}$ 9.096/95 não tratou de criação ou modificação de partidos políticos, mas tão somente de seu funcionamento parlamentar, cujas restrições não seriam vedadas pela Constituição Federal. Ademais, aduziu inexistir ofensa ao princípio da igualdade, uma vez que o próprio sistema político-eleitoral pressupõe tratamento diferenciado, na proporção da representatividade popular, entre agremiações grandes e pequenas, sendo legítima a limitação à atuação dos últimos. Tal restrição estaria em consonância com a previsão de necessidade de "caráter nacional” dos partidos, expresso no artigo 17, inciso I da Carta Magna. Acrescentou que, apesar de o artigo $7^{\circ}$ da lei em questão conceituar caráter nacional, os dois dispositivos referem-se a momentos diversos da existência do agrupamento político, cabendo então critérios distintos para a verificação da regularidade do requisito. A plenitude partidária, pois, seria reservada aos chamados partidos autênticos, que assim seriam entendidos os que se sustentam em adesão de parcela razoável da população.

Em sentido semelhante, a Procuradoria-Geral da República ofertou parecer pela improcedência das ações, afirmando que a liberdade da organização das legendas não é 
ilimitada, ressaltando também o requisito do caráter nacional, e cuja indeterminação admitiria a definição de seus contornos pela lei. Aduziu ainda que a redução da cota-parte no rateio do fundo partidário e do tempo de divulgação em meios de comunicação em massa observam justamente o princípio da isonomia, tornando tal participação proporcional à representatividade.

O relator, Min. Marco Aurélio de Mello, iniciou seu voto pontuando que apenas a Carta outorgada de 1967 teria versado sobre matéria semelhante à cláusula de barreira em discussão. Naquela oportunidade, não apenas restringia o funcionamento parlamentar, mas condenava à extinção a agremiação que não obtivesse dez por cento da votação na última eleição para a Câmara dos Deputados, percentual que viria a ser flexibilizado na Emendas Constitucionais 1/69, 11/78 e 25/85.

Tratando da Constituição de 1988, o relator continua seu voto afirmando que a liberdade de criação, incorporação e fusão de partidos políticos ali estabelecida não admite uma regulamentação que classifique as legendas como sendo de primeira ou de segunda classe, muito menos que se condene à inanição partidos pequenos, cuja existência jurídica se tornaria estéril sem a atividade parlamentar concreta, e cujo desenvolvimento seria impossibilitado sem a chance de divulgação de seu perfil junto ao eleitorado e sem recursos econômicos para a própria manutenção. Passa então o Ministro relator àquele que seria o elemento central de seu voto: a ênfase dada pela Constituição Federal à representação das minorias, garantindo aos partidos políticos a representação proporcional nas comissões temporárias e permanentes da Câmara dos Deputados e Senado Federal (art. 58, §1 ${ }^{\circ}$ ), sem exigir votação mínima. Lembra ainda que o quórum para a criação de Comissões Parlamentares de Inquérito é minoritário (um terço da respectiva casa) e que qualquer partido com representação no congresso, por menor que seja, possui legitimidade para provocar a jurisdição constitucional concentrada.

Continua o relator discorrendo que tais dispositivos constitucionais, que garantem direitos à minoria, "encerram a neutralização da ditadura da maioria, afastando do cenário nacional óptica hegemônica e, portanto, totalitária”. Admitir-se um partido político legitimado a propor ações diretas de inconstitucionalidade e declaratórias de constitucionalidade e, ao mesmo tempo, negar-lhe funcionamento parlamentar, resultaria em absoluta incongruência do sistema, sem que tal restrição sequer se desse por via constitucional. Lembrando ainda que a 
eleição de um parlamentar, mesmo em partido muito pequeno, só ocorre se for da vontade popular.

Por fim, o Min. Marco Aurélio resgata discussão relacionada à revisão constitucional, ocorrida em 1994, em que, através de substitutivo apresentado pelo então deputado Nelson Jobim, se tentou a inclusão, no texto da Magna Carta, dos $\S \S 5^{\circ}$ e $6^{\circ}$ no artigo 17, que teriam redação semelhante ao do artigo 13 da Lei $n^{\circ}$ 9.096/95. Naquela oportunidade, seria ainda acrescentado que apenas os partidos que cumprissem a mencionada condição poderiam registrar candidato a Presidente da República. Não houve, então, consenso para a aprovação do substitutivo. O texto ali rejeitado acabou aprovado em norma infraconstitucional. Com base nesses fundamentos, acolheu o pedido formulado e declarou a inconstitucionalidade do artigo 13 da Lei $\mathrm{n}^{\circ}$ 9.096/95 e, por arrastamento, dos demais artigos que o mencionam.

Já o Ministro Gilmar Ferreira Mendes pondera que o legislador poderia, sim, fixar cláusula de desempenho, sem a necessidade de alterar o texto constitucional, e exemplifica com o dispositivo que estabelece que a distribuição de mandatos pela sobra de votos só é possível para a legenda que atinge o quociente eleitoral, o que já encerra um sistema favorável a partidos de maior representação. Ocorre que, em seu entender, foi extrapolado o poder regulamentar, uma vez que estar-se-ia comprometendo o funcionamento parlamentar em sua totalidade, para os partidos pequenos. Afrontaria, assim, o princípio da proporcionalidade. Esclarece ainda que reconhece a legitimidade da preocupação do congresso, que diagnosticou sinais de exaustão de nosso presidencialismo de coalizão, demonstrado em sucessivas crises, deixando, assim, espaço para o reconhecimento da constitucionalidade de uma cláusula restritiva mais branda.

Em sentido semelhante ao de seus colegas, o Min. Ricardo Lewandowski ressalta a ausência de razoabilidade e proporcionalidade do dispositivo sob exame, utilizando, assim como o relator, a expressão "ditadura da maioria" para se referir ao malferimento do princípio básico de proteção às minorias ideológicas que teria sido cometido. Também o Min. Eros Roberto Grau aponta o que seria um "despotismo da maioria” e, citando Carl Schmitt, cobra igualdade de chances para que qualquer tendência ou movimento tenha oportunidade de se tornar majoritário, sem o que haveria uma perpetuação das mesmas forças políticas no poder.

Em sequência, os Ministros Carmem Lúcia e Carlos Ayres de Britto voltam a mencionar o desrespeito à proporcionalidade, uma vez que, segundo o último, mais que um 
obstáculo, o dispositivo legal, o qual nomeia "cláusula de caveira", estaria a prever uma verdadeira exclusão da atuação das agremiações. Em aparte, o Min. Sepúlveda Pertence, concordando que a cláusula teria extrapolado o poder regulamentar, pondera, no mesmo sentido do colega Gilmar Mendes, que não se deve, com fundamento no pluralismo, condenar antecipadamente toda e qualquer modulação que se faça no funcionamento do parlamento com base em desempenho eleitoral, ressaltando que institutos desta ordem são encontrados no direito comparado, exemplificando com o modelo alemão.

Em voto cujo fundamento destoa consideravelmente dos colegas, o Min. Cezar Peluso afirma que seria admissível se o legislador restringisse a própria existência do partido que não atingisse o desempenho mínimo previsto, mas, não o tendo feito, não poderia restringir dessa forma a atuação parlamentar de uma legenda que o próprio sistema decidiu por manter existente. Afirma, no entanto, que deve ser feita diferença entre o pluralismo previsto na Constituição Federal e um multipartidarismo fragmentado que, em seu entender, não serve propriamente à proteção de minorias. Por fim, a Min. Ellen Gracie Northfleet concorda com a possibilidade de o dispositivo legal restringir atuação de partidos, mas também destaca a desproporcionalidade com a qual tal fora feito.

O Supremo Tribunal Federal, assim, por unanimidade, julgou procedentes, nos termos do voto do relator, as ações diretas 1351 e 1354, declarando a inconstitucionalidade do artigo 13 da Lei $\mathrm{n}^{\circ}$ 9.096/95, bem como os demais dispositivos que o mencionavam, ressalvando ou lhe atribuindo efeitos no tempo. A famigerada cláusula de barreira, então vigente há mais de 11 (onze) anos, deixava o ordenamento jurídico às vésperas de estrear seus plenos efeitos, tornando sem sentido toda a movimentação realizada pelas legendas para satisfazer sus critérios, antes e mesmo após o pleito eleitoral de 2006.

\section{A NOVA CLÁUSULA DE DESEMPENHO PREVISTA NA EMENDA CONSTITUCIONAL N 97/2017.}

As ações diretas de inconstitucionalidade 1351 e 1354 encerraram um capítulo no cenário político brasileiro, mas não a discussão a respeito de uma nova formatação partidária mais enxuta, que trouxesse contornos mais claros ao jogo político. A própria fundamentação da decisão deixou aberta essa possibilidade, quase como que convidando os parlamentares a criarem um novo modelo, repensando o nível de restrição que, dessa vez, iria ser imposto a 
minorias. Em meio a cobranças por uma reforma política mais ampla, muito se debateu, nas duas décadas do Século XXI, sobre regras mais rígidas de fidelidade partidária, limitação de coligações em eleições proporcionais, mudança do sistema para voto distrital ou em lista fechada ou em sistema misto, possibilidade de candidatura sem vinculação a partido, forma de financiamento, restrições a doações, gastos e períodos de campanha, etc. Chegou-se até mesmo a debater com alguma seriedade a possibilidade de uma constituinte exclusiva para a realização desta reforma política (TRINDADE, 2010, online).

É verdade que, em alguns dos quesitos acima, pouco ou nada se avançou. No que toca ao objeto de nosso estudo, entretanto, houve considerável inovação normativa relativa à cláusula de desempenho. Em 04 de outubro de 2017, foi promulgada a Emenda Constitucional $\mathrm{n}^{\circ}$ 97, que alterou parágrafos do artigo 17 da Constituição Federal, que passaram a vigorar com a seguinte redação:

Art. 17..........................................................................................
$\S 1^{\circ}$ É assegurada aos partidos políticos autonomia para definir sua estrutura interna
e estabelecer regras sobre escolha, formação e duração de seus órgãos permanentes e
provisórios e sobre sua organização e funcionamento e para adotar os critérios de
escolha e o regime de suas coligações nas eleições majoritárias, vedada a sua
celebração nas eleições proporcionais, sem obrigatoriedade de vinculação entre as
candidaturas em âmbito nacional, estadual, distrital ou municipal, devendo seus
estatutos estabelecer normas de disciplina e fidelidade partidária.

$\S 3^{\circ}$ Somente terão direito a recursos do fundo partidário e acesso gratuito ao rádio e à televisão, na forma da lei, os partidos políticos que alternativamente:

I - obtiverem, nas eleições para a Câmara dos Deputados, no mínimo, 3\% (três por cento) dos votos válidos, distribuídos em pelo menos um terço das unidades da Federação, com um mínimo de $2 \%$ (dois por cento) dos votos válidos em cada uma delas; ou

II - tiverem elegido pelo menos quinze Deputados Federais distribuídos em pelo menos um terço das unidades da Federação.

$\S 5^{\circ}$ Ao eleito por partido que não preencher os requisitos previstos no $\S 3^{\circ}$ deste artigo é assegurado o mandato e facultada a filiação, sem perda do mandato, a outro partido que os tenha atingido, não sendo essa filiação considerada para fins de distribuição dos recursos do fundo partidário e de acesso gratuito ao tempo de rádio e de televisão.

Assim como no regramento anterior, foi estabelecido, no artigo $3^{\circ}$ da mesma Emenda, uma gradação na exigência do filtro. Desta forma, para a atual legislatura, que se seguiu às eleições de 2018, a condição para acesso ao fundo partidário e à propaganda gratuita em rádio e televisão foi fixada em 1,5\% (um vírgula cinco por cento) dos votos válidos, distribuídos por pelo menos um terço das unidades da federação, com um mínimo de $1 \%$ (um 
por cento) dos votos válidos em cada uma delas ou, alternativamente, que o partido tenha logrado eleger ao menos nove Deputados Federais, em pelo menos um terço das unidades da federação. A cada legislatura tem-se um pequeno aumento de exigências, de forma que aquelas que constam dos parágrafos transcritos valerão a partir das eleições de 2030.

Em comparação com a cláusula estudada nos tópicos I e II, verificam-se algumas diferenças sensíveis, a primeira de caráter formal, e as demais de natureza material: a) a opção pela espécie emenda constitucional, em substituição à lei ordinária; b) o estabelecimento de exigência menos rigorosa no que diz respeito ao percentual de votos a ser obtido; c) as consequências ligeiramente diversas que decorrem do não atendimento dos critérios estabelecidos.

Como seria de se esperar, a Emenda Constitucional 97 já foi objeto de ação direta de inconstitucionalidade. O Partido Renovador Trabalhista Brasileiro - PRTB, que não atingiu a votação mínima exigida e não elegeu um deputado sequer, ajuizou (em 31 de janeiro de 2019, já posteriormente ao resultado do pleito eleitoral de 2018 e na véspera da posse dos parlamentares da nova legislatura) a ação direta de inconstitucionalidade 6.063, que ainda não teve o pedido de liminar julgado. Dos 30 (trinta) partidos que elegeram deputados no último pleito, 09 (nove) não atingiram a votação ou número de eleitos exigidos para acesso a recursos e propaganda gratuita, encontrando no Supremo Tribunal Federal a última esperança de garantir o acesso a tais expedientes.

\section{ANÁLISE CRÍTICA DOS DISPOSITIVOS DA CLÁUSULA DE DESEMPENHO TRAZIDA NA EMENDA CONSTITUCIONAL Nº 97, À LUZ DOS FUNDAMENTOS UTILIZADOS NAS ADIs 1351 e 1354.}

No segundo tópico do presente artigo analisou-se os fundamentados apresentados pelos ministros julgadores das ações diretas de inconstitucionalidade relacionadas à cláusula de barreira prevista na Lei $n^{\circ} 9.096 / 95$. Os fundamentos apresentados para julgar procedente o pedido servem de norte para avaliar se as modificações, formais e materiais trazidas pela cláusula restritiva de 2017, tornam superada a inconstitucionalidade apontada. A diferença formal sensível entre os dois institutos é o estabelecimento, em 1995, por lei ordinária e, em 2017, por emenda constitucional. A indagação que merece ser feita em relação a tal ponto é se 
o caráter infraconstitucional da primeira norma teve repercussão na conclusão por sua inconstitucionalidade.

Analisando os fundamentos de cada voto, a conclusão é, inevitavelmente, negativa. Ainda que, de forma marginal, o relator e alguns outros julgadores, notadamente os ministros Gilmar Mendes e Carlos Ayres de Britto, tenham mencionado en passant a opção feita pelo legislador, de condição hierárquica pouco elevada na escala normativa, tais observações constituem mero obter dictum, não compondo a razão de decidir e, assim, não formando um precedente a ser seguido em julgamento posterior. Frise-se que a grande maioria dos julgadores, incluindo aí os próprios ministros Gilmar Mendes e Carlos Ayres de Brito, manifestaram-se expressamente pela possibilidade de estabelecimento de uma cláusula de desempenho por legislação ordinária, contanto que resguardasse a proporcionalidade e a garantia de representação de minorias, o que pode ser delimitado como a ratio decidendi do acórdão.

Estabelecido que a lei ordinária é meio legítimo para aplicar uma restrição ao funcionamento partidário que seja proporcional e que garanta a representação de minorias, poder-se-ia ainda insistir na questão formal indagando: a opção pela Emenda Constitucional autorizaria ir mais longe que a via ordinária? Em outras palavras, admitir-se-ia, naquela hipótese, que se avançasse sem respeito à proporcionalidade e ferindo o pluralismo ideológico garantido pelo constituinte originário? Mais uma vez a resposta seria negativa. O princípio do pluralismo (ARON, 1968), tantas vezes citado no acórdão das ADIs 1351 e 1354, tem nítido caráter contramajoritário, encerrando direito fundamental e, como tal constitui cláusula pétrea, nos termos do art. $60, \S^{\circ}$, IV da Constituição Federal. É possível discutir se o Supremo agiu corretamente ao considerar que o artigo 13 a Lei $n^{\circ}$ 9.096/95 feriu o princípio do pluralismo. O que não cabe é, partindo-se da matéria já decidida pelo Excelso Pretório, concluir que tal afronta seria admissível por meio de Emenda Constitucional.

A conclusão sobre o meio utilizado pelo Congresso Nacional, portanto, não poderia ser outra: valer-se de uma Emenda Constitucional, ainda que possa revestir o defensor da norma de um poder retórico ao demonstrar a força da maioria qualificada que o aprovou, tecnicamente em nada modifica a análise de constitucionalidade.

Passa-se então ao conteúdo da norma. Seria ela materialmente constitucional? A resposta já não é objetiva. 
Como dito, a razão de decidir consagrada nas ADIs deixa clara a impossibilidade de uma restrição que não respeite os princípios do pluralismo e da proporcionalidade. Se não é possível dizer, sem adentrar uma zona cinzenta, se a Emenda Constitucional $\mathrm{n}^{\circ} 97$ é compatível com tais princípios, que encerram conceitos indeterminados, pode-se partir da conclusão, feita pelo Supremo Tribunal Federal, que tal compatibilidade não estava presente no artigo 13 da Lei ${ }^{\circ}$ 9.096/95. Comparando materialmente as duas normas, vê-se que na última: a) foi abrandado o requisito do percentual de votos; b) foi, em parte abrandada, em parte agravada a consequência do não atingimento.

Quanto ao percentual mínimo de votos, este não foi um tema tratado com grande relevo na decisão do Supremo Tribunal Federal. Apesar de serem mencionados partidos que não o atingiram, o ponto de corte estabelecido não foi o cerne da questão. Pela fundamentação apresentada, a lei seria inconstitucional por esvaziar por completo a atividade e a capacidade econômica e publicitária das legendas pequenas, mas que possuem parlamentares eleitos. Essa realidade não se altera com a mera ampliação do filtro, fazendo com que tais consequências drásticas se apliquem a um menor número de agremiações. Ter-se-ia, a partir de uma interpretação da leitura da decisão, apenas uma maioria ainda maior oprimindo uma minoria ainda menor.

Assim, chega-se à diferença que realmente importa quando se analisa a constitucionalidade da nova cláusula de barreira: a consequência de seu não atingimento que deve ser estabelecida de forma proporcional e respeitando o princípio do pluralismo inserto no artigo 17 da Constituição Federal. Nesse ponto, pede-se licença ao leitor para uma rápida digressão, pois cabe aqui uma crítica a respeito da extensão do pluralismo partidário que foi estabelecida na decisão. Não parece correto que, ao dificultar a atividade das legendas pequenas, a lei esteja a oprimir minorias ideológicas (HONNETH, 2003). A representação destas independe de garantias a uma excessiva fragmentação partidária. Em verdade, circunscrever tais minorias em agremiações pouquíssimo relevantes no cenário político enfraquece sua representação. Pequenos partidos não significam representação de minorias.

Nessa questão, aderimos integralmente ao pensamento do ministro Cezar Peluso, que, mesmo concordando com a inconstitucionalidade da cláusula, assim se manifestou:

[...] quero dizer que a mim não me repugna e - na minha visão - não repugna tampouco ao sistema jurídico constitucional vigente, um tratamento normativo que, embora prestigiando o pluralismo, evite o que os autores costumam chamar de 
“multipartidarismo", essa pulverização, fragmentação que - a meu ver - , com o devido respeito, não serve propriamente a proteção de minorias, como tais, suscetíveis de múltiplas configurações, mas serve, antes, a expressar, em termos de representação, ideias e concepções políticas - No sentido mais amplo da palavra, de convivência na polis, como projeto de convivência ética -que compunha um corpo organizado dentro da sociedade. Duvido muito que dentro dessa sociedade, qualquer que ela seja, possa encontrar-se, nesses termos, "corpus" organizado de ideias ou de visão do mundo que ultrapasse a duas ou três dezenas, quando qualquer sistema poderia admitir pluralidade tal de partidos que comportaria, por exemplo, o "Partido de produtores de banana do vale do Ribeira". acho que não é essa a função do sistema partidário, até porque a tutela e a proteção de minorias podem ser objeto de programas partidários. As minorias podem ser tuteladas, podem ser protegidas por qualquer partido, cujo programa as contemple.

Independente de que visão se adote a respeito do multipartidarismo "à moda brasileira”, é certo que o Excelso Pretório decidiu que a Constituição garante que qualquer regulamentação da esfera política permita que tais pequenos partidos não tenham esvaziadas sua capacidade de manter-se íntegros como um corpo orgânico funcional, representando a parcela do povo que elegeu seus afiliados. Para saber se a nova regra assim agiu, deve-se fundamentalmente analisar a consequência de não se atingir o ponto de corte.

$\mathrm{Na}$ cláusula de desempenho declarada inconstitucional, as consequências eram: a) entrar no rateio de apenas $1 \%$ do total do fundo partidário; b) o direito a somente dois minutos de programas semestrais em rede nacional para divulgação de suas propostas, ao invés dos quarenta reservados aos demais partidos, que ainda possuem tempo de propaganda no âmbito estadual e inserções publicitárias; c) a perda de direitos regimentais à bancada, como participações em comissões e direitos da liderança respectiva. A nova regra instituída pela Emenda Constitucional $\mathrm{n}^{\circ} 97$ é ainda mais rígida quanto aos itens $a$ e $b$ acima, retirando por completo a participação no fundo partidário e o direito a qualquer tempo gratuito em rádio ou televisão. Já o item $c$ foi suprimido, de forma que não há restrição à atuação do partido no quotidiano parlamentar.

Em resumo, o partido que elege congressistas mas não cumpre a cláusula de desempenho terá atuação parlamentar com todos os direitos regimentais preservados, mas sem o patrocínio estatal, correspondentes ao acesso a fundo partidário ou tempo gratuito de rádio e televisão. Teria a nova regra superado as objeções estabelecidas pelas ações diretas de inconstitucionalidade 1351 e 1354 ? Dito de outra forma, seria ela proporcional e respeitaria o princípio do multipartidarismo?

A resposta não é pacífica, mas entendemos que a recuperação da plena atuação parlamentar ameniza sensivelmente o flagelo que se impunha ao partido pequeno. Quanto às 
outras consequências, hoje, quase 15 (quinze) anos após o julgamento das ações diretas de inconstitucionalidade, o cenário da discussão é bem diferente. A publicidade em rádio e televisão já não tem o mesmo peso. $\mathrm{O}$ universo das mídias sociais e as publicações eletrônicas em geral, cujos custos são bem mais acessíveis que a publicidade televisiva, assumiram um protagonismo na forma de divulgação e de circulação das informações na esfera pública, especialmente no cenário eleitoral (KAKUTANI, 2018). Já a manutenção do fundo partidário tem sido objeto de questionamentos pela sociedade civil, minando a argumentação de legendas pequenas no sentido de ter um direito inalienável à própria manutenção às custas do fundo.

O que parece é que, muito mais do que apresentar uma nova formatação da cláusula de desempenho que atacasse as falhas da anterior, apontadas pelo Supremo Tribunal Federal, o Congresso Nacional apostou na mudança de paradigmas e mentalidade ocorrida desde então, acreditando que o momento seria adequado à aceitação de um novo regramento. De fato, até mesmo um ministro que participou do julgamento das ações diretas de inconstitucionalidade afirmou publicamente, em 2017, que muitos na corte reconhecem que aquela declaração de inconstitucionalidade foi uma intervenção indevida no sistema eleitoral (BRASIL, 2017, online).

Acredita-se, portanto, que a cláusula de barreira introduzida pela Emenda Constitucional $\mathrm{n}^{\circ} 97$ deveria ser declarada constitucional, continuando a produzir efeitos no sentido de restringir o fomento estatal a partidos que demonstrem não possuir suficiente representatividade popular (DAHL, 2012). Como efeitos práticos indiretos, espera-se uma redução numérica de tais legendas, que tenderão a fusões e incorporações, resultando em um espectro partidário com contornos mais nítidos ao eleitorado e em relações congressuais menos difusas.

\section{CONCLUSÃO}

A Lei $\mathrm{n}^{\circ}$ 9.096/95, que regulou a atividade partidária brasileira, criou um instituto popularmente conhecido como cláusula de barreira, ou de desempenho, que exigiu, objetivamente, a demonstração de uma representatividade mínima de cada agremiação para que pudesse manter em sua plenitude a atividade parlamentar, a participação no fundo partidário e o programa gratuito em rádio e televisão. Entendendo que a cláusula em questão 
havia afrontado os princípios do pluralismo e da proporcionalidade, o Supremo Tribunal Federal, em 2006, nas Ações Diretas de Inconstitucionalidade 1351 e 1354, a declarou inconstitucional, admitindo a possibilidade de o Congresso vir a editar um novo conjunto de regras menos gravosas, que não inviabilizassem por completo a atividade dos partidos considerados pequenos.

Em 04 de outubro de 2017 foi instituída nova cláusula de barreira, desta vez através da promulgação de uma Emenda Constitucional. Comparando-a com a regra anterior, vê-se que o Congresso Nacional reduziu a exigência de desempenho eleitoral e alterou a consequência para o não cumprimento. Analisando as ações diretas de inconstitucionalidade referentes ao primeiro regramento, conclui-se que era desnecessário, para efeito de constitucionalidade, modificar a espécie legislativa e permitir resultado eleitoral inferior. Entretanto, ao permitir o funcionamento parlamentar, sem restrições, dos partidos que não satisfizessem a cláusula, a Emenda Constitucional $n^{\circ} 97$ parece satisfazer a proporcionalidade e pluralidade desejadas pela corte suprema.

Considerando-se ainda que, desde o julgamento das ações diretas de inconstitucionalidade 1351 e 1354, houve importante diminuição de relevância das mídias televisiva e radiofônica - notadamente frente ao desenvolvimento das redes sociais e das publicações eletrônicas -, bem como verificou-se aumento da infâmia do fundo partidário, os efeitos do não atingimento dos critérios da cláusula de desempenho prevista na Emenda Constitucional 97 não mais parecem inviabilizar desproporcionalmente a atividade partidária. Assim, acredita-se que o cenário atual favorece a conclusão pela constitucionalidade da cláusula, que tende a trazer maior clareza ao cenário político partidário brasileiro.

\section{REFERÊNCIAS}

ARON, Raymond. Democracia y totalitarismo. Barcelona: Editora Seix Barral, 1968.

BRASIL. Projeto de Lei no 1670/1989, de 1989. . Brasília, Disponível em: JURÍDICO, Consultor. Partidos serão extintos se não atingirem votação mínima. 2006. Disponível em: https://www.conjur.com.br/2006-jul-14/partido_nao_atingir_votacao_minima_extinto. Acesso em: 28 set. 2020. Acesso em: 28 set. 2020.

BRASIL. Supremo Tribunal Federal. Ação Direta de Inconstitucionalidade $\mathrm{n}^{\circ}$ 1.351. Relator: Ministro Marco Aurélio. Brasília, DF, 07 de dezembro de 2006. Ação Direta de Inconstitucionalidade 1351. Brasília. Disponível em: 
http://redir.stf.jus.br/paginadorpub/paginador.jsp?docTP=AC\&docID=416150. Acesso em: 28 set. 2020.

BRASIL. Gilmar Mendes diz que STF errou em decisão sobre cláusula de barreira. 2017. Disponível em: https://www.camara.leg.br/noticias/509833-gilmar-mendes-diz-que-stferrou-em-decisao-sobre-clausula-de-barreira. Acesso em: 28 set. 2020.

DAHL, Robert. A democracia e seus críticos. São Paulo: Editora WMF Martins Fontes, 2012.

GOYARD-FABRE, Simone. O que é democracia. São Paulo: Martins Fontes, 2003.

GUERREIRO, Gabriela. Prona e PL se unem e criam o Partido da República. 2006.

Disponível em: https://www1.folha.uol.com.br/folha/brasil/ult96u85879.shtml. Acesso em: 28 set. 2020.

HABERMAS, Jürgen. Direito e democracia. Rio de Janeiro: Tempo Brasileiro, 2003. HONNETH, Axel. Luta por reconhecimento. São Paulo: Editora 34, 2003.

JURÍDICO, Consultor. Partidos serão extintos se não atingirem votação mínima. 2006. Disponível em: https://www.conjur.com.br/2006-jul-

14/partido_nao_atingir_votacao_minima_extinto. Acesso em: 28 set. 2020.

KAKUTANI, Michiko. A morte da verdade. São Paulo: Intrínseca, 2018.

KELSEN, Hans. A democracia. São Paulo: Martins Fontes, 2003.

LOPES FILHO, Juraci Mourão. Os precedentes judiciais no Constitucionalismo brasileiro contemporâneo. $3^{\text {a }}$ edição. Salvador: Juspodivm, 2020.

MATAIS, Andreza. Apenas sete partidos atingem cláusula de barreira. 2006. Disponível em: https://www1.folha.uol.com.br/folha/brasil/ult96u84505.shtml. Acesso em: 28 set. 2020.

PTB. Convenção Nacional do PTB aprova incorporação do PAN e elege novo diretório. 2006. Disponível em: https://ptb.org.br/convencao-nacional-do-ptb-aprova-incorporacao-dopan-e-elege-novo-diretorio/. Acesso em: 28 set. 2020.

TOCQUEVILLE, Alexis de. Da democracia da América. São João do Estoril: Principia, 2007.

TRINDADE, Fernando A. G.. CONSTITUINTE EXCLUSIVA PARA A REFORMA POLÍTICA? 2010. Disponível em: https://www12.senado.leg.br/publicacoes/estudoslegislativos/tipos-de-estudos/textos-para-discussao/td-80-constituinte-exclusiva-para-areforma-politica. Acesso em: 28 set. 2020. 